\title{
Borderland Anxieties: Brexit, Upper Silesia and Irish Partitions in Recent Novels by Glenn Patterson and Szczepan Twardoch
}

\section{Introduction: A Comparative Framework for Minor Literatures}

Northern Ireland owes its existence to a partition of Ireland that took place a century ago. The knottiest problems involved in the UK's recent divorce with the European Union can be traced back not only to the Belfast Agreement of 1998 but also to the establishment of a new border, and a new borderland, in the island of Ireland in 1922 (Jenkins 2021). The same year (1922) saw the coming into effect of a partition of Upper Silesia, which was triggered by the events and decisions taken in 1921. Historical, political and cultural parallels like that proliferate once we zoom in on both regions (i.e., Northern Ireland and Upper Silesia), also commonly referred to as provinces. The primary focus of this essay is on literary representations of crises and anxieties connected with the transformations of the geopolitical statuses of those provinces. What I explore here draws heavily on the notions of minor literature ${ }^{1}$ and provincial rhetoric,

1 The term itself comes from Gilles Deleuze and Felix Guattari's work on Kafka, Kafka: Pour une littérature mineure (1975), translated into English as Kafka: Toward a Minor Literature. I want to acknowledge its provenance here although my usage is different from Deleuze and Guattari's, their emphasis on deterritorialization transmuting, in my discussion, into a sustained focus on the consequences of reimagining regional territories and identities, affected by the establishment of new or redrawn borders. 
originally developed in Tropy Konfliktu (Troping the Troubles) (Drong 114-115) and largely inspired by several illuminating concepts presented and explored in Edna Longley's and Richard Kearney's writings.

In what follows, from Edna Longley's essay "From Cathleen to Anorexiathe Breakdown of Irelands," I borrow an insistence on overcoming nationalist categories in Irish culture, including both the Republic of Ireland and Northern Ireland. In her essay, Longley is quite emphatic about a future-oriented thinking that should transcend crude dichotomies (e.g. Nationalism vs. Unionism) to establish new, pluralist perspectives (194-195). I see her ideas as informing Eve Patten's notion of postnationalist literature (259-263), which, in turn, has much in common with the overarching concepts of postnationalism and postnationalist Ireland introduced by Richard Kearney. Kearney's skeptical attitude to all sorts of nationalisms is tersely expressed in his dismissal of both (Irish) republicanism and (British) unionism as "Siamese twins" (8). Kearney's study paves the way for my identification of minor literatures and minor cultures in Europe (and elsewhere) by paying close attention to "the distinct singularities that make up" (7) contemporary nations and states. The architects of Brexit, and similar geopolitical implosions of late, operate on the mistaken assumption that it is nations that share sentiments and identities whereas both contemporary and historical examples discussed below prove that cultural and ethnic nationalisms are fictions constructed to exercise (discursive) power over the singular self-identifications of differing social groups and ethnic communities, including numerous minorities.

As a consequence, my reading of two recent novels concerned with Northern Ireland and Upper Silesia may be identified as provincial. By a provincial reading I mean an unwavering focus on the vectors of social and political forces that undermine and compromise nationalist sentiments, often based on a brutally simplified rhetoric of "us vs. them." Internal oppositions, particularly rife, and often fueled from the outside, in Northern Ireland and Upper Silesia, require recourse to subtler and more nuanced categories, resulting in a conceptual "breakdown" (to come back to Longley's word) of both Ireland and Poland. In placing both novels in the context of BrexLit (Shaw 15) and partition literature, defined by Anna Bernard as "texts that represent either the event of territorial partition or its consequences" (10), I pay heed to Sara Upstone's reading of seminal works by such critics as Homi Bhabha, Edward Said and Benedict Anderson. Upstone is particularly alert to "the ways in which not only ... geographical borders shape identities and how we imagine them, but-conversely-how we imagine them shapes borders, resulting in a cultural authority which is unstable and ambivalent ..." (45). In the two novels to be discussed here, besides 
borders, nationalism is a common eminence grise, although the books are set in differing historical periods and their geopolitical circumstances seem to be quite distant. And yet, a single episode in Glenn Patterson's Where Are We Now?, which I discuss in the first part of this essay, telescopes time and brings to light cultural and historical continuities between Northern Ireland in the late $2010 \mathrm{~s}$ and Upper Silesia at the turn of the 1910s. Meanwhile, the setting of Szczepan Twardoch's Pokora constitutes a stark reminder of the historical configuration that led to the establishment of the Free Irish State and Northern Ireland in $1921,{ }^{2}$ the same year that Upper Silesia was partitioned into a German zone and a Polish zone, the new border taking effect in 1922. Partitions and borders make their spectacular appearance in both novels, thus drawing our attention to another overlap between Patterson's exploration of the post-referendum East Belfast and Twardoch's historical fiction about a Jederman from Upper Silesia.

Taken tout court, Szczepan Twardoch's writings do not yield to clear-cut national criteria and categories. His novels adopt varying perspectives and foci, with several works (including mostly Epifania wikarego Trzaski (Curate Trzaska's Epiphany), Drach and Pokora) being almost exclusively concerned with Silesia's history and contemporary cultural, social and political issues. That is why transnational categories seem to be more suitable for capturing Twardoch's position within Upper Silesian literature. Notwithstanding some crucial differences in historical and political contexts, I posit that Karolina Pospiszil's understanding of transnational literature, as constituting an element of a minor multiculture (51), responds to similar concerns to those raised in Kearney's discussion of Irish culture and politics. Those associations are not really new: still before the 2016 referendum I joined a research partnership with academics from several European universities, including Ulster University in Northern Ireland. ${ }^{3}$ What brought a number of us together was a keen interest in minority languages and cultures, especially those imperiled by nationalism and other tensions and pressures connected with centripetal forces at work in Polish and

2 Northern Ireland was formally established on May 3, 1921 when the Government of Ireland Act came into effect. For further details of the circumstances that led to the partition of Ireland, see Moore 42-53.

3 In 2016 the Centre for the Study of Minor Cultures was established at the University of Silesia in Katowice. The Centre concluded its existence in 2019 as a result of an administrative overhaul of research units at the University of Silesia. Over the three years our discussions and joint projects were largely concerned with Upper Silesia and its self-definition. Much of the inspiration for those projects came from our partnership with Ulster University in Belfast. 
British cultural politics. ${ }^{4}$ In a similar vein, Pospiszil's notion of transnational literature, much as it is indebted to Arjun Appadurai's anthropology and his category of the social imaginary, resonates with Kearney's postnationalism and Longley's insistence on "varied, mixed, fluid and relational kinds of identity" (195). Recent crises on the peripheries of the European Union (what we often assume to be the margins of "our" Europe)_like Brexit in Northern Ireland and recent waves of aggressive fundamentalism and militant "turbopatriotism" (Napiórkowski 14) in Poland-have thrown those counter-nationalist categories (i.e. postnationalism and transnationalism) into relief.

In Where Are We Now? (2020), Glenn Patterson seeks to produce a panorama of Belfast struck by the calamitous economic and social ramifications of the 2016 referendum and impending Brexit. And yet there are other themes there, too, and those include a narrative equivalent of a historical trip to Upper Silesia. Patterson's readers are invited to reflect on a diversion that takes them back to the early 1920 s and one of the most important battles fought during the so called Third Silesian Uprising (1921). ${ }^{5}$ The digression is of interest to those who see historical and political parallels between local histories in Upper Silesia in the wake of the Great War on the one hand and Northern Ireland post 2016 referendum on the other. ${ }^{6}$ What Patterson describes in his novel is just a beginning of an extended process of economic decline and political hardships triggered by the referendum (Doyle, Connolly 141-145; Tonge) and still likely to be exacerbated by the ongoing redefinition of the Irish border from 2021 onwards. Most novels by Patterson are set in Belfast ${ }^{7}$, which, in his latest work, is more than just a milieu for his protagonists; his book is a nostalgic fresco of what will soon give way to a grim, non-EU reality of the post-Brexit Northern Ireland. Reading Where Are We Now? brings to mind watching The Last Picture

4 In their political analysis of the origins of Brexit, Sylvia de Mars et al. explore both centripetal and centrifugal forces at work in the British Isles following the Great War (de Mars et al. 2-3).

5 Ryszard Kaczmarek, in the most comprehensive and insightful discussion of the Silesian Uprisings to date, classifies the 1919-1921 conflict over Upper Silesia as a Polish-German war. His book is, in fact, subtitled: "An Unknown Polish-German War" (6).

6 Those parallels also concern the past and the present in Northern Ireland, as Landon E. Hancock claims, arguing "that Northern Ireland's identity narratives persist and continue to provide fertile ground to interpret new conflicts through the old lens of identity conflicts" (2014: 443-444).

7 Here are just a few emblematic examples: Burning Your Own (1988), Fat Lad (1992), The International (1999), Gull (2016). 
Show, the 1971 Peter Bogdanovich movie about the cultural and economic atrophy of a North Texas town.

\section{The Provincial vs. the National}

In Patterson's novel, the protagonist's daughter, Beth, is unemployed, having gone bankrupt in Great Britain. She comes back to Belfast to live with her father, Herbie, fully aware that in her case East Belfast spells decline and degraded professional and personal ambitions. Her initial attempts at finding gainful employment are unsuccessful; finally, she is offered a secretarial position with a company which produces films or, to be more exact, takes advantage of financial opportunities and tax incentives unavailable to foreign producers (an allusion to the circumstances that brought the crew of Games of Thrones to Northern Ireland). Beth's bosses are two young siblings from County Tyrone. They know little of film production but both are obsessed with the notion of popularizing their home county, placed in the central part of Northern Ireland and relatively obscure to foreign tourists. Failing to attract any major projects, they decide to sign German-Polish co-producers who want to make a movie about the Silesian Uprisings in the context of border disputes following the Great War. Both siblings, Roza and Micky, acknowledge that the theme of border disputes is close to their hearts, as it has also fueled many controversies in Northern Ireland.

Here is an excerpt to illustrate their attitude to the issues raised in the German-Polish movie. Interestingly, in their conversation, Roza and Micky single out the Irish border as a particularly useful asset:

The script called for a restaging, midway through the second act, of the battle of Annaberg, in which a combination of German Freikorps and ethnically German Poles succeeded in dislodging Polish insurgents from a hilltop monastery commanding the approach to the whole Oder valley. "There's much action in the boudoir, like, as there is on the battlefield," Roza said.

"They actually use the word boudoir in the script," Mickey chipped in, 'about once every two pages."

"If we can't find them a hill in the Sperrins to run up and down shooting their guns, I'm sure we can find them a four-poster bed and some fancy drapes if they want to keep the rating down. And we do have a genuine border we can offer them." 
"Genuine disputed border."

"If they need to, you know, get in the zone." (Patterson 2020: 127)

When they are about to start shooting battling troops, a problem with extras arises. No one wants to act as a German from the Freikorps. All the extras opt to be "Polish insurgents," rather than "Huns" or "Nazis" [sic!], as the local people choose to refer to the German soldiers involved in a 1921 Uprising. It is worth bearing in mind, at this point, that County Tyrone is known for its mostly nationalist population, with clearly defined republican sympathies. They are predominantly Catholic. Several prominent figures have made Tyrone famous, all of them being associated with the nationalist side of the Northern Ireland conflict, in some cases even before it actually started. Brien O'Nolan, better known as Flann O'Brien, a towering figure in twentieth-century Irish literature, was born there (in Strabane) in 1911; Robert Gerard Sands, commonly known as Bobby Sands, an Irish hero of the 1981 Hunger Strike, was elected Independent Republican Member of Parliament for Fermanagh and South Tyrone; the legendary O’Neill dynasty, with the last earl of Tyrone, Hugh O'Neill, who infamously fled Ulster in 1607 after an unsuccessful challenge to the Tudor rule in the north of Ireland, held territories mostly within what today is known as County Tyrone. That simple catalogue should make it crystal clear why the local people are eager to play insurgents while adopting a hostile attitude to the soldiers associated with the German Empire (ironically, it was the Weimar Republic between 1918 and 1933), even if the latter prevail in the restaged battle. In Northern Ireland, it is common social practice on the part of (Irish) nationalists to refer to Protestants as "huns" (Holmquist 2006).

It is not immediately clear why a novel set in contemporary Belfast should include a historical theme to do with Upper Silesia. Is Patterson's choice a matter of cultural and geopolitical contingency? Is the border issue the only pretext to allude to the inter-war situation in Upper Silesia and the battle of Annaberg?8 Not necessarily. Glenn Patterson is not the first and only author in the British Isles to highlight historical analogies between Northern Ireland and Upper Silesia. Timothy Wilson, in his book published in 2010, draws similar parallels (but also alerts us to some significant disparities) between the geopolitical circumstances of the establishment of Northern Ireland (involving a partition of the island of Ireland) and the circumstances responsible for the partition of Upper Silesia in 1921. The reason why in various contexts those two sets

8 A detailed analysis of the historical and symbolic significance of the battle, and of Annaberg itself, is offered in Węgrzynek 175-181. 
of circumstances are brought up today is that, a century gone by, they keep informing and illuminating the present. In both regions, by the way, the British played a significant role in shaping borders and cementing partitions. In Northern Ireland they safeguarded the emergence of a new country explicitly described as a "Protestant State"; in Upper Silesia they were members of an Inter-Allied Commission, which arrived there at the beginning of 1920 to act as an arbitration body (Wilson 2010: 29). The political conflict between the British and the French was largely responsible for the decision to hold a referendum over the future of Upper Silesia: the French favoured Poland as a beneficiary of the division of the spoils in the wake of the Great War while the British wanted Germany to keep most of its industrial potential associated with its Eastern borderlands (Lewandowski 2015: 27). No foreign representative in the Commission was in favor of giving voice to "the autochthons" (Kamusella 618), i.e. the native population of Upper Silesia. As a consequence, the border established in response to the joint French and Polish efforts largely ignored local interests and declarations. Once introduced (in 1922), it cut across many gardens, backyards, factory yards, tram routes and main roads in Upper Silesia (See: Strzeja 2007 for visual representations of divisions in Upper Silesia).

Wilson's work is mostly concerned with the sources and causes of violence in both regions but, on a larger scale, it is also a comparative "study of two conflicts over self-determination" (11). By juxtaposing two provinces and their multiplicity of tribes and sides to the conflicts, Wilson highlights what was brushed under the carpet on a political level: both the Partition of Ireland and the partition of Upper Silesia in 1921-1922 created political fictions out of complex ethnic, cultural, social, religious and linguistic configurations and conflicting interests. The aftermath of 1921 brought no simple division into winners and losers within the two regions while creating geopolitical conditions prone to antagonize the borderlanders. At the same time, it seems that the new borders have generated potential for new self-identifications. Border communities on both sides of each divide have often overcome animosities and crossed tribal lines to define and defend common interests, shared territory and emergent narratives of border identity (Nash, Reid 109). In this respect, the two novels, Pokora and Where Are We Now?, are markedly different. Twardoch has his protagonist cross several borders, past, present and future, what with the narrator's premonition of what is going to pass and what will soon call for redrawing the maps of Upper Silesia. Patterson's novel, in turn, does not venture beyond the city limits to visit the

9 Northern Ireland Prime Minister's words expressed in the Northern Ireland Parliament in 1934 (Buckland 231). 
Irish borderland but, by zooming in on an East Belfast community, it imparts a sense of suffocating isolation and oppressive constraint, comparable, perhaps, to what the Protestants felt during the siege of Derry at the end of the seventeenth century. In both fictions, borders define identities and encourage new identifications although the protagonists (both Alois and Herbie) do not find it easy to adjust to the changing circumstances and tend to cling on to the (recent) past. Where Are We Now? (its title clearly alluding to a sense of dislocation) begins with Herbie's telling response to the geopolitical whirligig in Northern Ireland in the wake of the 2016 referendum: "Someone had stolen his identity. An elaborate, thorough-going fraud stretching back years-decades" (Patterson 2020: 1). A sense of losing track of who he is emerges from what he perceives to be a medical condition. His doctor, however, puts his malaise in perspective, by offering him a broader picture: "look around you ... the whole world is unlike itself. Lord help us, you hardly know when you go to bed whether you are going to wake up in the same country" (Patterson 2020: 2). Likewise, Alois Pokora, once the Great War is over in 1918, complains about being lost and lonely, stranded in a place where Marx has replaced God (Twardoch 2020: 112): "I am a tight wreath of despair, fear, loneliness and loss. There is no God above me, there is no God inside me, there are no people by my side, there is no humanity in me. I have no one" (Twardoch 2020: 135). Asked whether he is Polish, he replies in the negative and insists that he is Upper Silesian (2020: 110-111), a citizen of a state that does not exist. For a brief moment before the 1921 Plebiscite, when he reads in a newspaper that there is a nebulous prospect of establishing an independent Upper Silesian state, he is agitated and hopeful (2020: 279; for a detailed discussion of Upper Silesian separatism, see Kijonka 86-89) but soon he realizes that he must be "forever homeless" (Twardoch 2020: 371), alienated from his own family and neighbours in what is to become, following the partition of Upper Silesia, part of the German zone.

Even though it promises to keep the Irish border practically as it has been since 1998, the agreement between the UK and the EU, reached minutes before the end of 2020, seems to appease neither Scottish nor Northern Irish parliaments (Carrell, Carroll 2020). What the Tories lost sight of is plain and simple to most of the people who live in Northern Ireland and Scotland: overnight they stopped being European, a crucial element of their identity, inextricably interwoven with their regional (or provincial) self-identifications. Glenn Patterson's attitude to identity issues is emblematic in this respect. In a 1998 interview with Elke D'Hoker and Hedwig Schwall (published two years later), he makes a significant claim not only about his books and ideas but also about the transnational categories that undercut divisions between the Irish and the 
British on the island on Ireland: "I don't believe in original states. The history of the world actually is just one of people moving all the time, as I've shown in the Euro-Disney book (i.e. Black Night at Big Thunder Mountain published in 1995). Hence I just wanted to create in my books some sense of constant movement..." (Patterson, D’Hoker and Schwall 93) This reads like a premonition of Stephen Greenblatt's insistence, in his 2009 manifesto of cultural mobility, on the need to abandon "the fantasy that once upon a time there were settled, coherent, and perfectly integrated national or ethnic communities" (Greenblatt et al. 2). And yet in the same text, Greenblatt, a decade wiser than Patterson in 1998, issues an admonition for the beginning of the twenty-first century to "those who thought to have bid farewell once and for all to the heavily guarded borders of the nation-state and to the atavistic passions of religious and ethnic identity": they may still "find themselves confronting a global political landscape in which neither nationalism nor identity politics shows any intention of disappearing" (1). A juxtaposition of the late 1910s and early 1920 s in many European countries with the current socio-political situation indicates that history runs in (vicious) circles.

In Patterson's fiction and non-fiction alike, divisions are often overcome by changing the dominant narrative of binary oppositions. From his first novel onwards, he opts for emphasizing the underlying humanity of his characters, having a Protestant Mal befriend a Catholic Francy in Burning Your Own against the backdrop of growing hatred and sectarian violence in Belfast's housing estates in the late 1960s. In Fat Lad and Gull, Patterson relies on distancing devices whereby the reader is offered (relatively) disinterested perspectives of outsiders who visit Northern Ireland and share their impressions. On a smaller scale, this is also how The International's protagonist, Danny, observes from the wings (as a barman) the unfolding of local history in The International Hotel in Belfast. Patterson's characters do not identify with a particular community or tribe but with a place, a province or, most commonly, with their city. Thus, they refuse to subscribe to any identity politics that reduces complex social structures to "two tribes of antagonists" (Sobolewska, Ford 218), as Maria Sobolewska and Robert Ford describe the divide between "Leavers" and "Remainers" in the context of Brexit. Patterson himself describes his characters' attitudes as "nonsectarian" (Hicks 111).

One of the most insistent self-identifications both Patterson's and Twardoch's protagonists are pressured to produce is a national one. In some of Patterson's novels tribal or sectarian identifications also make their appearance, particularly clearly delineated in Burning Your Own. However, those recently penned protagonists-e.g., Herbie in Where Are We Now? and Alois in Pokora-choose 
to identify with other imagined communities, i.e. homelands that are not recognized as states but merely as provinces, with all the legal and cultural implications of that status. Their provincial self-identifications are, at bottom, transnational and post-tribal/postsectarian, ${ }^{10}$ thereby neutralizing the antagonizing power of borderlines, separations and divisions imposed on the inhabitants of Northern Ireland and Upper Silesia, respectively. If Herbie and Alois have a quarrel to pick, it is with history and politics at large, and the people who thrive on disseminating discord (governments, political, religious or military leaders, etc.). In that context, those two works of literature are guidebooks for survival in the times of turmoil and crisis. Nationalism, in turn, appears to be a universal recipe for conflict and disaster.

Patterson's novel on post-referendum Belfast is not his only work concerned with the ramifications of the disastrous decision taken by the British on June 23, 2016. Alongside his fiction, in 2019 he published Backstop Land, a scorching critique of Brexit from the point of view of those who are likely to suffer its most grievous consequences. It is also a sarcastic take on identity politics, ${ }^{11}$ largely responsible for fueling conflicts and petrifying divisions in Northern Ireland. The 10 chapters that make up this book are prefaced by a brief prologue and a poem by Elaine Gaston (in itself deserving of an independent discussion): in each chapter Patterson lists paradoxes, quirks and absurdities following from the UK's decision to leave the EU. Centrally, however, Backstop Land is his way of venting outrage at the murder of Lyra McKee, a young journalist shot, in all likelihood, by a New IRA gunman on April 18, 2019. She was fired at, possibly by accident, during disturbances in the Creggan area of Derry (Quinn, Carroll 2020). Patterson's book may be read, then, not only as an elegy for Northern Ireland in the face of Brexit but first and foremost as a keening song for Lyra McKee, a representative of the generation of "the Ceasefire babies" (Patterson 2019: 88). Her murder showcases another paradox of Northern Irish society, ironically summed up by one of the characters of Robert McLiam Wilson's Eureka Street wondering "why anyone who might want the British to leave the Irish alone would announce this by killing Irish people" (227). In light of the

10 In the case of Patterson's novel, skeptical attitudes to Brexit and its consequences for Northern Ireland place its Protestant protagonists in a minority camp of those 40 per cent (of Protestants) who voted "Remain," rather than "Leave," on 23 June 2016 (McEvoy, Bryson and Kramer 637-638).

11 Backstop Land has much in common with another ironic treatment of the Brexit debacle, Fintan O'Toole's Heroic Failure. O’Toole likens the widespread British rhetoric of the sadomasochistic relationship between the UK and the EU to the terms of the contract signed between the Submissive and the Dominant in Fifty Shades of Grey (O'Toole 21-25). 
multiple, complex ethnic and geopolitical divisions within Northern Ireland, Patterson's book reads also like a parody of his own 1988 novel: Backstop Land might be subtitled Shooting Your Own instead of Burning Your Own. Apropos of the Irish border, Patterson makes a point, accentuated over and over again by recourse to examples of internal rifts within apparently tight knit communities, that simplistic binary divisions are useless for those who live on the spot: "Land borders are curious. Unless defined by a geographical feature-river, mountain range-they most often run between people who, broadly speaking, have more in common with one another than either has with their respective capitals" (Patterson 2019: 129). All in all, Backstop Land is a clarion call for recognizing difference and multiplicity of interests and perspectives among people who are doomed to share the same non-EU fate.

\section{Ominous Centenaries (1921-2021)?}

Pokora ${ }^{12}$ by Szczepan Twardoch is both a soliloquy and a love letter that a German soldier from Upper Silesia starts writing while still in the trenches of the Great War. Wounded and heart-broken, he barely reaches the end of the war and soon is exposed to new social, political and historical upheavals. In Germany and in Poland the year 1918 is a powerful caesura marking the beginning of a new order and new calamities for many inhabitants of those two countries, including Upper Silesians, whose existence was, at that time, vexed to a nightmare ${ }^{13}$ by irredentist tensions (Kornprobst 8-9; Peled 64). An agon of opposing nationalist sentiments ${ }^{14}$ in Upper Silesia became the driving force for the tests of divided loyalties and for a campaign of fear and violence in anticipation of the 1921 referendum, called the Plebiscite. It is hard to resist the impression that the German-Polish conflict over Upper Silesia in the years 1919-1921 is a prefiguration of the Troubles in Ulster and then in Northern Ireland (both in the early 1920 s and in the years following 1968). If Twardoch's fiction seems, at first sight, unreliable as a foundation for comparative ventures from Eastern peripheries of Europe to Northern Ireland, Peter Polak-Springer's historical account of irredentism in Upper Silesia between 1918 and 1939 should resonate

12 Pokora is a common surname in Upper Silesia; literally, the name translates into English as humility.

13 The phrase, borrowed from "The Second Coming" by William Butler Yeats, is a fitting expression for historical reasons, too. Yeats's poem was written in 1919.

14 Andrew Demshuk describes entire Silesia as "a strategic borderland” with a long history of territorial claims made by German, Polish and Czech nationalists (Demshuk 33). 
with those who remember the pre-Troubles period and then the Northern Ireland conflict itself:

Throughout the interwar era, governments in Germany and Poland struggled against one another to reacculturate landscapes and renationalize inhabitants in the district and larger region. Each side deployed its own cadre of borderland nationalists (activists supported by the government, including state agents, paramilitants, scholars, folklorists, literati, and other specialists of irredentist politics) ... These nationalists waged a cultural contest over this borderland in reaction to, and in imitation of, one another's “cultural propaganda," namely, discourses, propaganda tactics and nationalization policies. (Polak-Springer 3 )

In Twardoch's novel, in turn, there are historical and political accents, selectively highlighted by the producers of the German-Polish movie to be shot all over Tyrone in Patterson's novel, that anticipate the "heroic failure" of Brexit, to borrow Fintan O'Toole's phrase.

Twardoch's protagonist, Alois Pokora, experiences the turmoil of the Third Silesian Uprising first hand, initially placed in Gliwice (German Gleiwitz) and then forced to flee his recent Prussian comrades across what will soon be officially established as the German-Polish border. While still enjoying a steady job and the blessings of a loving family, he finds his anxieties writ large in a newspaper article (in German):

In the first page, there is a huge heading: Oberschlesien in Aufruhr, unrest in Upper Silesia, then they write that all railway traffic has been halted and telephone and telegraph lines have been severed; no, I cannot force myself to read this; even without my reading Silesia is going to be divided, some of it will be given to the Pollacks, Rybnik and Pszczyna, or they will get it all, or nothing; I am too tired to read this, I am too tired of this politics; may this be over; may they establish this border; may rest and peace come here; may men cease running to and fro with rifles; may the police handle the criminals, may they disarm the workers because now there is always a drunken brawl, and then a fight; before the war we would have settled it with a fistfight; today we settle it with gun shots and grenade throwing. (Twardoch 2020: 499-500; my own translation)

The final section of Twardoch's novel is a perfect illustration of Timothy Wilson's claim made in his comparative study of the root causes of violence in Ulster 
and Upper Silesia in the aftermath of the Great War. Wilson insists that "Upper Silesian society was less divided, but its violence was more unrestrained. By contrast, Ulster society was more deeply polarized but its violence was less severe" (Wilson 5-6). It is worth noting that, for Wilson, Upper Silesia is synonymous with the area that became the plebiscite zone in 1921. Its borders are identified by the contested territory to which both Germany and Poland laid their claims following the Great War. The actual identity of the historical and geographical region is of little concern to those who divide it, pretty much like the national identity of the protagonist of Pokora. The title of the novel implies a peculiar identification of the (anti)hero, who seeks to narrate his own story and his own identity, with the novel itself and the personal (hi)story it communicates. Pokora is a historical novel inasmuch as its protagonist is not only a person but also a personification of the (mostly) untold history of Upper Silesia. What it shares with Patterson's novel is a sense of vertigo induced by the changing shapes of the local borders and the political transformations witnessed up close by the protagonists of both novels. In this sense, the partition of Upper Silesia in 1921, accidentally coinciding with the establishment of Northern Ireland, bears a striking resemblance to the fears and tensions accompanying the transformation of the border in the island of Ireland, a consequence of Brexit and the conclusion of the transition period at the beginning of 2021. Centenary thinking, so popular in the British Isles and increasingly popular in Upper Silesia, collapses time and transports us back and forth between two historical realities.

Of course, any analogies between those two realities and the novels that purport to represent them must be qualified by numerous caveats. Twardoch's novel is set in the late 1910 s and early 1920s, a period historically and politically distant from the crises of the turn of the 2010s while Patterson's recent fiction describes the current impasses generated by the 2016 referendum in the UK. Both, however, are painfully sensitive to the mechanisms of power, populism, tribalism and the pressures of national(ist) identification. In opposition to the popular sentiments in and about their regions/provinces (Upper Silesia and Northern Ireland, respectively), they offer "thick descriptions" in Clifford Geertz's sense of the formula (Geertz 3-32 and Denzin 83), rich in sociological insights rather than in historical complexity. Their juxtaposition in this essay is justified by the political patterns that both writers choose for our attention: Patterson invites associations between contemporary Northern Ireland and a markedly different region on the peripheries of Europe by emphasizing watersheds in their self-identifications while Twardoch smuggles in analogies with the present status of his heimat by reimagining its foundations in the past. Interestingly, in an interview connected with the publication of Pokora, Twardoch stresses parallels between Upper Silesia and Ireland in the wake of the 
Great War. He does so by adducing The Wind That Shakes the Barley directed by Ken Loach (Twardoch, Padoł 2020).

\section{Conclusion}

The collocation of Patterson's Where Are We Now? with Twardoch's Pokora is based on more than just the year of their publication (2020). Both novels represent the category of minor literature in the sense that their focus on identity issues privileges the provincial and the local over the national. In both novels, a sense of regional crisis and impending (and ongoing) disaster determines the protagonists' modi vivendi and operandi. It is doubtful whether Patterson had a larger design in mind choosing Upper Silesia's history for a backdrop to one of his book's episodes. But his choice does have transnational and transcultural ramifications which invite comparative approaches to varying cultures and communities. I read it as an encouragement to think beyond the national paradigm and seek bridges over wide European expanses to span regions whose political statuses and economic circumstances have been afflicted by what Fintan O'Toole calls, in the context of the British Isles, "fantasies of Empire 2.0" (O'Toole 3). In East-Central Europe those fantasies may have taken different shapes but the predominant rhetoric of contemporary Polish nationalists is governed by the same inexorable logic of identity politics (Wike 52). In fact, Brexit has already antagonized not only the British and the Irish but also those people who live in various parts of Poland. East of Berlin, attitudes to the European Union amount to markers of political identity (Wysocki 6o-61). A hundred years ago, in 1921, when both Upper Silesia and Ireland were partitioned, a destructive potential for further divisions and antagonisms, like a malicious genie, was let out of the geopolitical bottle.

In both novels I have discussed here, the emphasis is put on transcending borders and communicating across barricades: Alois Pokora, perhaps because of his provincial background, finds it relatively easy to win trust and make friends with a number of figures from various circles and social classes, whether German, Silesian or Polish. Herbie and his daughter take Brexit in their stride, without looking for a sectarian scapegoat or abandoning their hopes of making better lives. Transnational and postnational perspectives that emerge from Patterson's and Twardoch's works count as proactive responses to the current crises, if only by illustrating available narrative patterns of dislocation and aporias of personal and collective identities. Characters in those novels confront history, whether distant or recent, without preconceived notions of which side they should choose. Eventually, they go their own, non-binary way, 
paved by instinct and confidence in local or family ties. Their attitudes to Brexit, divisions in Northern Ireland and the Uprisings and partition of Upper Silesia indicate that there are distinct axiological categories they may rely on, even in the absence of self-identifications involving loyalty to national communities. Toutes proportions guardées, both Where Are We Now? and Pokora address similar anxieties and basic aporias of uprootedness, displacement, misappropriation and identity crises. Both novels exact and perform a new geopolitical framework for provincial, transnational and postnational categories illustrated by their protagonists and their social settings.

\section{| Works Cited}

Bernard, Anna. "Forms of Memory: Partition as a Literary Paradigm.” Alif: Journal of Comparative Poetics 30 (2010): 9-33.

Buckland, Philip. "'A Protestant Parliament and a Protestant State': Regional Government and Religious Discrimination in Northern Ireland, 1921-39." Eds. A. C. Duke and C. A. Tames. Britain and The Netherlands. Dordrecht: Springer, 1981. 231-242.

Carrell, Severin and Rory Carroll. "Holyrood and Stormont Reject 'disastrous' Brexit Trade Deal." The Guardian, 30 Dec. 2020, https://tinyurl.com/3a6sfcuz. Accessed 14 January 2021.

de Mars, Sylvia et al. Bordering Two Unions: Northern Ireland and Brexit. Bristol: Policy Press, 2018.

Demshuk, Andrew. "Reinscribing Schlesien as Śląsk: Memory and Mythology in a Postwar German-Polish Borderland." History and Memory 24.1 (Spring/ Summer 2012): 39-86.

Denzin, N. K. Interpretive interactionism. Newbury Park, CA: Sage, 1989.

Doyle, John and Eileen Connolly. "Brexit and the Northern Ireland Question." The Law \& Politics of Brexit. Ed. Federico Fabbrini, Oxford: Oxford University Press, 2017. 139-159.

Drong, Leszek. Tropy konfliktu. Retoryka pamięci kulturowej we współczesnej powieści północnoirlandzkiej. Katowice: Wydawnictwo Uniwersytetu Śląskiego, 2019.

Geertz, Clifford. The Interpretation of Cultures: Selected Essays. New York: Basic Books, 1973.

Greenblatt, Stephen et al. Cultural Mobility: A Manifesto. Cambridge: Cambridge University Press, 2009. 
Hancock, Landon E. "Narratives of Identity in the Northern Irish Troubles." Peace \& Change 39 (2014): 443-467.

Hicks, Patrick. "A Conversation with Glenn Patterson.” New Hibernia Review/Iris Éreannach Nua 12.2 (2008): 106-119.

Holmquist, Kate. "Sectarian badges of identity." The Irish Times, May 6, 2006. https://tinyurl.com/w2hxkcz4. Accessed 14 January 2021.

Jenkins, Simon. “Boris Johnson's Brexit Shenanigans Have Met Their Reckoning in Northern Ireland." The Guardian, 8 March 2021, https://tinyurl.com/4sm6r6bx. Accessed 9 March 2021.

Kaczmarek, Ryszard. Powstania ślaskie 1919-1920-1921. Nieznana wojna polsko-niemiecka. Kraków: Wydawnictwo Literackie, 2019.

Kamusella, Tomasz. The Politics of Language and Nationalism in Modern Central Europe. London: Palgrave Macmillan, 2009.

Kearney, Richard. Postnationalist Ireland: Politics, Culture, Philosophy. London and New York: Routledge, 1997.

Kijonka, Justyna. Tożsamość współczesnych Górnośląaków. Studium socjologiczne. Katowice: Thesaurus Silesiae, 2016.

Kornprobst, Markus. Irredentism in European Politics: Argumentation, Compromise and Norms. Cambridge: Cambridge University Press, 2008.

Lewandowski, Jan F. Czas autonomii. Chorzów: Alkmena, 2015.

Longley, Edna. The Living Stream: Literature and Revisionism in Ireland. Newcastle upon Tyne: Bloodaxe Books, 1994.

McEvoy, Kieran, Anna Bryson and Amanda Kramer. "The Empire Strikes Back: Brexit, the Irish Peace Process, and the Limitations of Law." Fordham International Law Journal 43:3 (2020): 609-667.

Moore, Cormac. Birth of the Border: The Impact of Partition in Ireland.

Newbridge: Merrion Press, 2019.

Napiórkowski, Marcin. Turbopatriotyzm. Wołowiec: Wydawnictwo Czarne, 2019.

Nash, Catherine and Bryonie Reid. Partitioned Lives: The Irish Borderlands. London: Routledge, 2013.

O’Toole, Fintan. Heroic Failure: Brexit and the Politics of Pain. London: Head of Zeus, 2018.

Patten, Eve. "Contemporary Irish Fiction." The Cambridge Companion to the Irish Novel. Ed. J. W. Foster. Cambridge: Cambridge UP, 2006. 259-75.

Patterson, Glenn, Elke D’Hoker and Hedwig Schwall. "Interview with Glenn Patterson." Études irlandaises 25.1 (2000): 91-101.

Patterson, Glenn. Backstop Land. London: Head of Zeus, 2019.

---. Where Are We Now? London: Head of Zeus, 2020.

Peled, Yoav. The Challenge of Ethnic Democracy: The State and Minority Groups in Israel, Poland and Northern Ireland. London and New York: Routledge, 2014. 
Polak-Springer, Peter. Recovered Territory: A German-Polish Conflict over Land and Culture, 1919-1989. New York and Oxford: Berghan Books, 2015.

Pospiszil, Karolina. “Transnarodowa literatura górnośląska? Rozważania o próbach tworzenia kanonu małej literatury." Joseph von Eichendorff (1788-1857) a česko-polské kulturní a umělecké pohraničí / Joseph von Eichendorff i czesko-polskie kulturowe i artystyczne pogranicze. Ed. Lubomir Martinek. Opava: Slezská univerzita v Opavě, KLP - Koniasch Latin Press, 2018. 49-62.

Quinn, Ben and Rory Carroll. "Lyra McKee: man, 52, charged with murder of journalist." The Guardian, 12 Feb. 2020, https://tinyurl.com/45kzyu86. Accessed 14 January 2021.

Shaw, Kristian. "BrexLit”. Ed. Robert Eaglestone, Brexit and Literature: Critical and Cultural Responses. London and New York: Routledge, 2018.15-30.

Sobolewska, Maria and Robert Ford. Brexitland: Identity, Diversity and the Reshaping of British Politics. Cambridge: Cambridge University Press, 2020.

Strzeja, Szymon. "Jak powstawała granica polsko-niemiecka w powiecie rybnickim.” 2007. https://tinyurl.com/x8jzkczr. Accessed 14 January 2021.

Tonge, Jonathan. "The Impact and Consequences of Brexit for Northern Ireland," 2017, https://tinyurl.com/62c56753. Accessed 14 January 2021.

Twardoch, Szczepan and Emilia Padoł. "Lubię moje życie w całości. Smakuje mi ta dziwna, kręta historia." Onet, 16 Sept. 2020, https://tinyurl.com/wykr5tds. Accessed 14 January 2021.

---. Pokora. Kraków: Wydawnictwo Literackie, 2020.

Upstone, Sara. “Do Novels Tell Us How to Vote?” Ed. Robert Eaglestone, Brexit and Literature: Critical and Cultural Responses. London and New York: Routledge, 2018. 44-58.

Węgrzynek, Krystian. Języki mitu historii, religii w literaturze na Górnym Śląsku. Analiza wybranych dzieł $x \mathrm{x}$ wieku regionu pogranicza. Katowice: Wydawnictwo Uniwersytetu Śląskiego, 2018.

Wike, Richard et al. European Public Opinion Three Decades After the Fall of Communism. Pew Research Center, October 2019, https://tinyurl.com/yw77egau. Accessed 14 January 2021.

Wilson, Robert McLiam. Eureka Street. London: Vintage, 1998.

Wilson, Timothy. Frontiers of Violence: Conflict and Identity in Ulster and Upper Silesia 19181922. Oxford: Oxford University Press, 2010.

Wysocki, Artur. "Poczucie tożsamości narodowej Polaków w kontekście zachodnioeuropejskim." Opuscula Sociologica 3.21 (2017): 57-77. 


\section{| Abstract \\ Leszek Drong \\ Borderland Anxieties: Brexit, Upper Silesia and Irish Partitions in Recent Novels by Glenn Patterson and Szczepan Twardoch}

Northern Ireland owes its existence to a partition of Ireland that took place a century ago. The knottiest problems involved in the UK's recent divorce with the European Union can be traced back not only to the Belfast Agreement of 1998 but also to the establishment of a new border, and a new borderland, in the island of Ireland in 1922. The same year (1922) saw the coming into effect of a partition of Upper Silesia, which was triggered by the events and political decisions taken in 1921. The primary focus of this essay is on literary representations of crises and anxieties connected with the transformations of the geopolitical statuses of the two provinces (i.e. Northern Ireland and Upper Silesia) and selected historical, political and cultural parallels between them. Those anxieties are exemplified and illustrated by the leading characters of Glenn Patterson's Where Are We Now? (2020) and Szczepan Twardoch's Pokora (2020). Both novels yield to provincial readings that explore basic aporias of uprootedness, displacement, deterritorialization and identity crises, collectively identified here as borderland anxieties. In consequence, transnational and postnational perspectives that emerge from Patterson's and Twardoch's works count as proactive responses, encoded in literary texts, to current geopolitical crises in Europe.

Keywords: minor literature; postnationalism; borders; Northern Ireland; Upper Silesia; Brexit

\section{| Abstrakt}

\section{LESZEK Drong}

Lęki graniczne. Brexit, Górny Śląsk i podziały Irlandii w powieściach: Where Are We Now? Glenna Pattersona oraz Pokora Szczepana Twardocha

Irlandia Północna zawdzięcza swoje istnienie podziałowi wyspy Irlandii, którego dokonano 100 lat temu. Najtrudniejsze do rozwiązania problemy związane z niedawnym „rozwodem” między Unią Europejską a Zjednoczonym Królestwem sięgają nie tylko podpisanego w 1998 roku porozumienia z Belfastu (tzw. porozumienia wielkopiątkowego), ale również ustanowienia granicy na wyspie Irlandii w 1922 
roku oraz ukonstytuowania się obszarów przygranicznych. W tym samym 1922 roku pojawiła się granica dzieląca na pół Górny Śląsk - na część polską i niemiecką. Została wprowadzona na mocy decyzji politycznych podjętych w 1921 roku. Poniższy esej skupia się na literackich przedstawieniach kryzysów i lęków związanych z transformacjami geopolitycznymi dwóch regionów określanych często jako prowincje - Górnego Śląska i Irlandii Północnej - oraz na wybranych zbieżnościach historycznych, politycznych i kulturowych. Przykładem, a zarazem ilustracją takich lęków są postaci występujące w powieściach: Glenna Pattersona pt. Where Are We Now? (Gdzie teraz jesteśmy?) i Szczepana Twardocha pt. Pokora. Obie powieści zachęcają do „prowincjonalnej lektury”, w której na plan pierwszy wysuwają się kategorie wykorzenienia, wysiedlenia, przemieszczenia, deterytorializacji oraz kryzysu tożsamości, które to kategorie zbiorczo określam jako lęki graniczne. Transnarodowe i postnarodowe optyki, jakie ujawniają się w lekturze powieści Pattersona i Twardocha, można uznać za wbudowany w tekst literacki prewencyjny zabieg lub też przestrogę przed współczesnymi kryzysami geopolitycznymi nękającymi Stary Kontynent.

Słowa kluczowe: literatura mniejsza; postnacjonalizm; granice; Irlandia Północna; Górny Śląsk; brexit

\section{| About the Author}

Leszek Drong is Professor of the Humanities in the Institute of Literary Studies, the University of Silesia in Katowice. He is also Associate Dean for Research in the Faculty of Humanities as well as President of the Polish Association for Irish Studies. His most recent book was published in 2019: Tropy konfliktu. Retoryka pamięci kulturowej we współczesnej powieści pótnocnoirlandzkiej [Troping the Troubles: The Rhetoric of Cultural Memory in Recent Novels from Northern Ireland]. He has also recently published in Critique: Studies in Contemporary fiction, Estudios Irlandeses, Studia Litteraria Universitatis Iagellonicae Cracoviensis and Przeglad kulturoznawczy. His primary research interest is in the intersection of Irish studies, cultural memory studies and border studies.

E-mail: leszek.drong@us.edu.pl

ORCID: 0000-0001-8395-013X 